\title{
STOCK EXCHANGES OF BALTIC COUNTRIES: DEVELOPMENT AND PROSPECTIVES
}

\author{
Romualdas Ginevičius, Manuela Tvaronavičienė \\ Vilnius Gediminas Technical University, Saulètekio al. 11, LT-2040 Vilnius, Lithuania. \\ E-mail: manuela@post.omnitel.net
}

Received: 16 January, 2003

\begin{abstract}
The paper deals with Stock Exchanges of Lithuania, Latvia and Estonia. Authors tackle issues related with differences and peculiarities, activity and prospects of development of the Stock Exchanges. The main emphasis has been put on looking for the best solutions for effective functioning of Lihuanian Stock Exchange. Various variants of privatization have been considered.
\end{abstract}

Keywords: Stock Exchange of Lithuania, Latvia and Estonia, activity, integration, globalizationn, privatization

\section{Introduction}

Lithuanian stock exchange is the last one still owned by the state: Latvian and Estonian governments already sold their stock exchanges to a strategic investor. Now Lithuania has to make a decision and this decision could influence the future of capital market: will it grow in the future and benefit all its stakeholders, contribute to national wealth and economic development?

A country's economy cannot function properly unless it is possible for people and companies to save or borrow money in order to make investments, insure their property and possessions etc. Unreliable banks, unclear rules for trading with securities etc. create problems for economic growth. The backbone of a market economy is an efficient and stable financial system. It makes the country more attractive to foreign investors and distributes local capital in such a way that makes it possible to lend savings to investors for use in interesting projects that can create growth.

\section{World Stock Market's Trends}

In recent years, the securities exchange sector has changed dramatically, at both a European and a global level. Since the early 1990 s, there have been several trends:

- The demutualization of exchanges

- The globalization of financial markets and financial operations

- The introduction of new information and communication technologies

- Greater access to capital markets

The demutualization of a number of exchanges has resulted in pressure to consolidate markets. At the same time, alternative trading systems on networks operating in parallel with traditional marketplaces have emerged, offering advantages such as the possibility of cross-border trading and lower transaction costs.

These developments, combined with an increase in the number of participants (banks, investment service providers, etc), have significantly increased market 
activity, making the European stock exchange sector a dynamic, high-growth industry which is open to competition.

During this period of variation, alternative trading networks appeared. These included Jiway, launched in November 2000 by OM Gruppen, and Virt-X/Tradepoint, launched in June 2001. Other developments included the Milan stock exchange's acquisition of the Italian clearing and settlement organization in July 2002, the Norex alliance between the Stockholm exchange and the exchanges of Oslo, Copenhagen and Iceland, and ongoing discussions between Finland's exchange, which operates the markets in Estonia and Latvia, and the Warsaw exchange.

Outside Europe, the Toronto Stock Exchange was listed on its own market, and the New Zealand exchange announced in September 2002 that it would demutualize. Nasdaq acquired Easdaq in 2001, and announced the launch of Nasdaq Deutschland (scheduled for March 2003), in which Nasdaq will hold $50 \%$ of the shares, with the remainder being held by the regional markets in Berlin and Bremen and a consortium of banks including Commerzbank and Dresdner Bank.

In the derivatives sector, Chicago Mercantile Exchange Holdings, the parent company of the largest options and futures exchange in the US, was listed on the New York Stock Exchange on 6 December 2002. At the end of 2002, the London Stock Exchange announced the formation of EDX London, an international derivatives market, in connection with OM Gruppen (which has a $24 \%$ interest).

The proposed revision of the European Directive on Investment Services, which was adopted on 19 November 2002 by the European Commission, creates a new regulatory framework for order execution systems, such as multilateral trading facilities (MTF), and the internalization of order execution by investment service providers as defined by the directive (banks or investment companies). This proposal relaxes the transparency requirements that used to apply to centralized regulated markets. The directive sets out the role to be played by information systems within the industry, and the changes this will entail for the European financial markets should stimulate innovation.

\section{European Securities Market}

\subsection{Growing Competition}

Struggle between stock exchanges and also among bourses and organizers of alternative trading have strengthened extremely in a couple of last years. Growing competition for capital markets, members and listed companies make stock exchanges to seek for bigger liquidity, lower costs, effective management, to inculcate advanced technologies, innovatory products, to remove treats to international securities trade. More and more bourses try to accomplish these tasks by consolidating own resources with other stock exchanges.

With the formation of the European Union, crossborder trading in Europe is growing in popularity. The introduction of the euro and a wider acceptance of equity as a financing tool are encouraging investors in Europe to engage in more cross-border transactions in search of profit-making opportunities. Yet despite the appeal of cross-border trading, most stock exchanges in Europe are national institutions that trade only local, country-specific stocks.

This market structure appears to be changing, however, as an increasing number of stock exchanges are attempting to operate across national borders. Several ambitious initiatives have been undertaken of late to create, through mergers or other consolidations, pan-European exchanges that offer trading in stocks from many European countries. The establishment of these exchanges will likely lead to important benefits for the financial markets. For example, a standardization of trading platforms across exchanges, an increase in market liquidity, and a reduction in market fragmentation-potential by-products of consolidationcould help minimize the costs and problems associated with cross-border trading in Europe. Table 1 below shows how market capitalization of developed economies changes in 5 years.

As mentioned earlier, the launch of the euro has led to a rapid development of European capital markets (Table 1) and created a particular need in Europe for exchanges that provide cross-border trading of securities. But even before introducing new Euroland's currency the need for changes in securities market and especially in trading was clearly seen. Globalization, emergence of global companies and global capital flows - all this and many more things showed that selling and buying securities at national level is no longer satisfactory: companies need more funds, investors seek for diversification, stock exchanges, not only in Europe, are looking for possibilities to lower their cost. Today we can find quite lots of stock exchanges in Europe, even not mentioning that there are more than 20 in the European Union, and the number of clearing and settlement agents is around the same. Clearly, equity trading in Europe was and still is in the need of consolidation. 
Table 1. Market capitalization in Developed economies in US\$ millions [1]

\begin{tabular}{lrrrrr}
\hline & $\mathbf{1 9 9 7}$ & $\mathbf{1 9 9 8}$ & $\mathbf{1 9 9 9}$ & $\mathbf{2 0 0 0}$ & $\mathbf{2 0 0 1}$ \\
\hline United States & 11.308 .779 & 13.451 .352 & 16.635 .114 & 15.104 .037 & 13.810 .429 \\
Japan & 2.216 .699 & 2.495 .757 & 4.546 .937 & 3.157 .222 & 2.251 .814 \\
United & & & & & \\
Kingdom & 1.996 .225 & 2.374 .273 & 2.933 .280 & 2.576 .992 & 2.217 .324 \\
France & 674.368 & 991.484 & 1.475 .457 & 1.446 .634 & 1.174 .428 \\
Germany & 825.233 & 1.093 .962 & 1.432 .190 & 1.270 .243 & 1.071 .749 \\
Canada & 567.635 & 543.394 & 800.914 & 841.385 & 700.751 \\
Italy & 344.665 & 569.731 & 728.272 & 768.364 & 527.396 \\
Spain & 290.383 & 402.180 & 431.668 & 504.219 & 468.203 \\
Netherlands & 468.736 & 603.182 & 695.209 & 640.456 & 458.221 \\
Sweden & 272.730 & 278.707 & 373.278 & 328.339 & 232.561 \\
Finland & 73.322 & 154.518 & 349.409 & 293.635 & 190.456 \\
Denmark & 93.766 & 98.881 & 105.293 & 107.666 & 94.958 \\
Ireland & 49.371 & 66.596 & 68.773 & 81.882 & 75.298 \\
Norway & 66.503 & 46.944 & 63.696 & 65.034 & 69.054 \\
Austria & 35.724 & 34.106 & 33.025 & 29.935 & 24.511 \\
Iceland & 1.859 & 3.106 & 4.807 & 4.439 & 3.552 \\
\hline
\end{tabular}

Consolidation has been under way for a couple of years. Traditional exchanges have tried to counter increasing competition from electronic exchanges, socalled ECNs (Electronic Communication Networks) by adding other capabilities (e.g. the ability to trade across borders) and to decrease their costs by increasing their market shares, volumes and liquidity. So far, the driving forces have been the big old names from the established financial centers like London, Paris and Frankfurt. The aim has ranged from the not so ambitious, the increase of co-operation, to the more ambitious, the merger of traditional exchanges in order to create larger markets, more liquidity and, thus, lower costs.

But not only had leading stock exchanges taken actions to reorganize the whole trading system as we know it today. Indeed Western financial Europe was concerned about new challenges they face but they were not the only ones. Great efforts were taken from Scandinavian bourses in order to become the setoff to some alliances now founded in the "Old Europe". It is enough to mention such a big name like OM Gruppen. This company was founded as a private company in 1985 and owns and has managed the Stockholm Exchange, which was privatized in 1993, since 1998. It operates six other commercial exchanges as well, mainly in London, the Nordic countries and Canada. But OM is not only a traditional exchange; it is also a technology company. A large bulk of OM's profits comes from its development of highly sophisticated trading platforms and clearing and settlement systems. OM is therefore both an exchange operator and a provider of technology. OM is consequently highly lucrative; since its foundation 15 years ago, $\mathrm{OM}$ has grown exponentially and is today worth nearly $4 \mathrm{bn}$ euro. Nowadays the influence of this "wale" might be seen in a number of decisions taken in financial world. But still its wills are not always realized as they wished it would be.

In today's life it is very hard to predict future trends precisely because of great competition, new technological solutions, risk factors and even cultural obstacles. The last proposition might be illustrated with unsuccessful attempt to form Euronext alliance in 1998, when such big names like London Stock Exchange, Deutsche Börse and Paris bourse could not come to the agreement which exchange is going to be the leader. Discontent that started among European countries a few centuries ago is still alive and the influence of it might be felt on the large scale. Never the less one is obvious - sooner or later the number of bourses will go down to just a few, which are going to represent European equity market (Fig. 1).

The first step towards was significant increase in cross-border trading. Two recent developments have broadened the appeal of cross-border trading in Europe and brought it into new level. The first was the introduction of the euro. As a growing number of countries have adopted the euro the risk associated with an unexpected change in exchange rates has diminished, making cross-border investment more desirable. Significantly, the increased use of the euro has been accompanied by the removal of some regulatory restrictions on European capital flows.

Second, the emergence of an equity culture across Europe has made cross-border investment more common. In the past, most European countries relied 


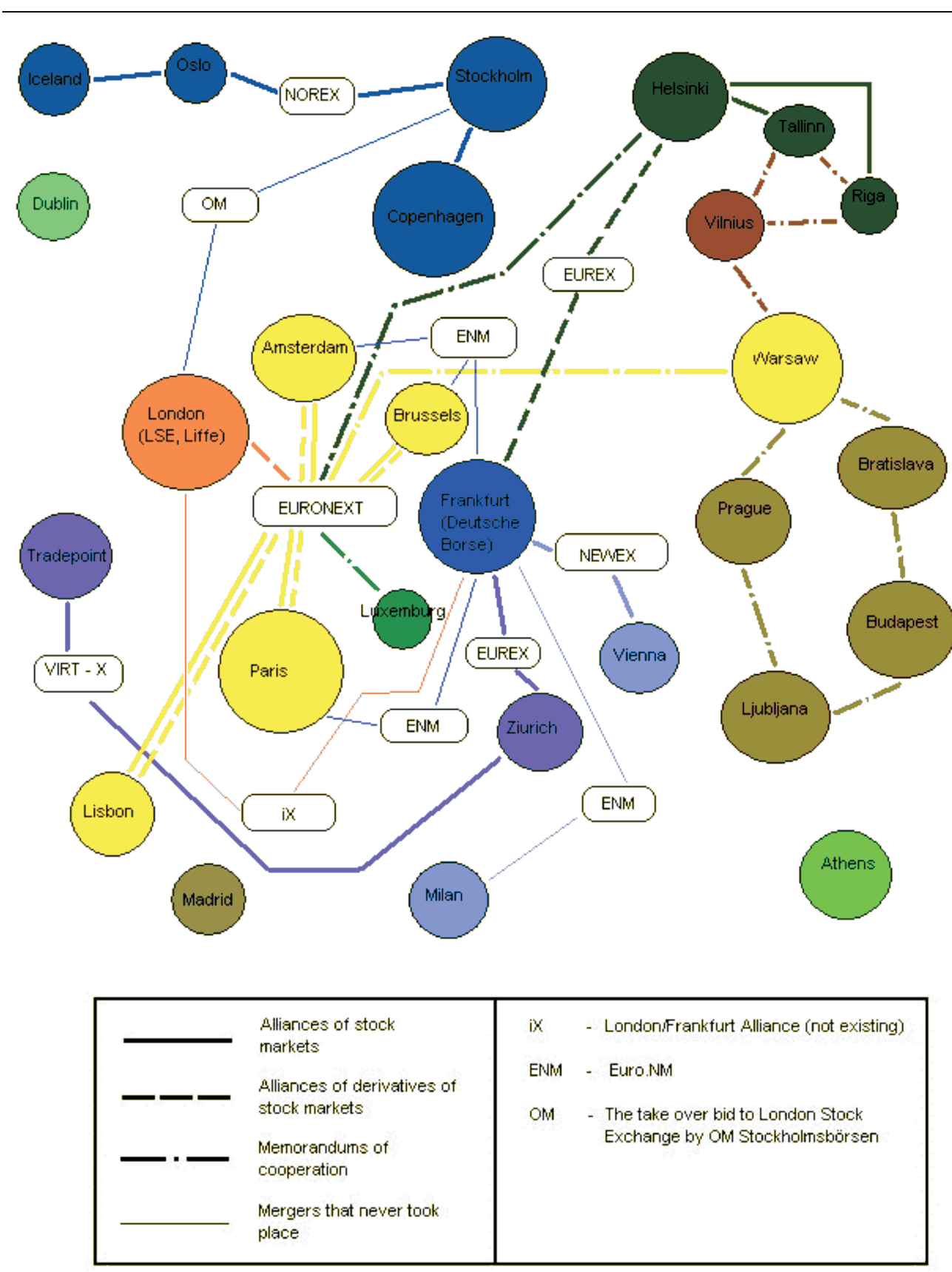

Fig. 1. Cooperation between stock exchanges in Europe

on bank-oriented financial systems: investors deposited a large portion of their savings in banks, and the banks played a major role in providing financing to the industry. More recently, however, equity has developed into a popular method of financing, as shown by the rise in share ownership in several European countries. For instance even in emerging post-Soviet countries the part of local investors is increasing and after reforms made in pension systems the amount of investments should improve considerably.

\subsection{The reformation of stock exchanges into public companies}

The tendency to reform stock exchanges into public companies, which started before 9-10 years, has strengthened in recent years: 2000-2001. Competitive environment, markets' globalization, the need for capital to finance new and developing markets - all this and more stimulate traditional stock exchanges to change their status from closed stock companies to public companies. In Europe majority of stock 
exchanges have already became public companies, which distributed their shares and started to list them on own listings.

On February 2001 Deutsche Börse successfully issued own shares. Totally on primary public offer there were issued 3200151 shares of which 419676 were acquired by stockholders, 27741 - by employees and all other shares, about $80 \%$ (2,75 mil.) were sold to institutional investors. Issued shares were listed on Deutsche Börse list.

On the year 2001 Oslo Exchanges became the last stock company from exchanges of Nordic countries. On $8^{\text {th }}$ of May 2001 Oslo bourse started to trade own shares. Till the end of May the exchange distributed 5 mil. of shares $(100 \%)$. For one share holder there was a limited amount: not more than $10 \%$ of all stock. Most of the shares were sold to institutional investors from Norway, $20 \%$ were bought by foreign investors. The part of all share was also bought by own employees. There is no intention to list these shares on trading lists in the short run, but Orkla Enskilda Securities are going to announce quotations through the system of non-listed shares.

In the middle of the year 2001 Euronext distributes 12,2 mill. of already issued shares and 16,7 mill. of new shares for 693 mill. EUR. Through this emission the exchange raised 400 mill. EUR. All stock was issued to international institutional investors through closed session and to small investors in the countries of Euronext alliance through public offer. Since $6^{\text {th }}$ of July 2001 shares of Euronext are listed on official lists in Euronext exchanges.

On the year 2000 London Stock Exchange was reorganized into stock company. Since the beginning of trading its shares the amount changed from 297 till 1500 and mostly investment and risk funds became new owners. On 20 of July 2001 shares of London Stock Exchange were listed on its own listing. Just before the listing of shares, shareholder decided to remove restriction that one package of shares can have only $4,9 \%$ of all stock. This decision ended the reorganization of London Stock Exchange into stock company.

\section{Baltic Stock Exchanges - In a Transition From the Past to the Future}

The introduction of the euro has had, and continues to have, a major impact on the European financial sector. The further integration of the financial sector throughout the euro area will continue in the future as the monetary integration will strengthen the effectiveness of monetary policy transmission and contribute to greater efficiency and competitiveness of the euro area's real economy. It is also of interest to Baltic States, as they have to guide their own integration process with the euro area. All three, belonging to accession countries, are already preparing legal systems and financial sectors to fulfil the requirements set by authorities of the EU. And today important steps forward are already visible: increasing harmonization of the regulatory framework and the integration of underlying financial structure. Below capitalization of stock exchanges of emerging economies can be compared during 5 years of development.

Baltic States come quite a short way of financial development yet but even these several years created different situation while talking about capital markets. Lithuania, though being the first one to establish the stock exchange, is the last one to sell it to a strategic investor. In such situation the experience of other states could be used.

Capital markets in all three countries are still small and not yet fully developed in terms of market segments and instruments (Table 2). They play only a minor role in the whole economy of a country. In general capital markets had indeed been set up in all three countries, and even quite early in terms of other post-Soviet countries, but market developments were not very strong. Throughout the period of existence of stock markets many delistings have occurred, all markets were and still are dominated only by a few big firms, allowing little room for investors to diversify their portfolio and for medium sized companies to attract funds. The debt market was also experiencing difficulties, as the low level of government debt, although welcome from a public finance viewpoint, implied a low level of available securities. And the corporate debt market is small and of little significance. It was clear that in such conditions the attraction of foreign investors for both, stock and bond markets, was crucial.

\subsection{Short Description of Baltic Stock Exchanges}

The recent financial crisis in world markets (East Asia in 1996, US in 2001, the recession in Europe) created confusion among the world's investors. But for the Baltic States it also created a new opportunity: investors who had diversified their portfolios with stocks traded in emerging Asian or old European 
Table 2. Market capitalization of emerging economies [1]

\begin{tabular}{lrrrrr}
\hline & $\mathbf{1 9 9 7}$ & $\mathbf{1 9 9 8}$ & $\mathbf{1 9 9 9}$ & $\mathbf{2 0 0 0}$ & $\mathbf{2 0 0 1}$ \\
\hline Russia & 128.207 & 20.598 & 72.205 & 38.922 & 76.198 \\
Poland & 12.135 & 20.461 & 29.577 & 31.279 & 26.017 \\
Hungary & 14.975 & 14.028 & 16.317 & 12.021 & 10.367 \\
Czech Republic & 12.786 & 12.045 & 11.796 & 11.002 & 9.331 \\
Croatia & 4.246 & 3.190 & 2.584 & 2.742 & 3.319 \\
Slovenia & 1.625 & 2.450 & 2.180 & 2.547 & 2.839 \\
Romania & 627 & 1.016 & 873 & 1.069 & 2.124 \\
Estonia & 1.101 & 519 & 1.789 & 1.846 & 1.483 \\
Ukraine & 3.667 & 570 & 1.121 & 1.881 & 1.365 \\
Lithuania & 1.693 & 1.074 & 1.138 & 1.588 & 1.199 \\
Latvia & 337 & 382 & 391 & 563 & 697 \\
Slovakia & 1.826 & 965 & 723 & 742 & 665 \\
Bulgaria & 2 & 992 & 706 & 617 & 505 \\
Macedonia & 8 & 8 & 8 & 7 & 46 \\
\hline
\end{tabular}

markets began to look for new havens for their investments.

For many, the Baltic States seem to be just the right place: low price-earnings ratios (the region's average stock price is less than ten times projected 1998 earnings per share), dividend yields that are relatively high for rapidly-growing companies $(2 \%-5 \%)$, and constantly improving market regulations are all contributing to the increasing popularity of the region among international investors. The Baltic States Lithuania, Latvia and Estonia - lie in the very heart of Europe. The Baltics seem to belong to one homogeneous entity. All three states are small open economies, highly dependent on oil products and natural gas, with a similar geographical position and natural resources. Moreover, years of Soviet rule have left the same pattern on the way of life, mentality, and culture. But although having so much in common, they have achieved different results during the transition and have different growth prospects over the long run. The reasons lie much deeper than is usually supposed. Looking closer the three states differ in religion and culture, history and political preferences, structure of industry and trade, and many other aspects that influence the behavior and development of independent units.

This section will provide a general overview of Baltic stock markets and examine the differences and similarities among them, their mechanisms and features. The main aim of this part is to give an essential understanding of the stock markets of Estonia, Latvia, and Lithuania.

Many western investors first imagine the Baltics to be an extension of the Russian market. But most of them soon discover that political stability and market regulation are in far better condition in the Baltic
States than in Russia. On the other hand, the region's market capitalization of US $\$ 3,4$ billion is dwarfed by Russia's total of US\$76 billions (2001). The small size also has an impact on liquidity and volatility: often foreign orders, which are small- or medium-sized in Western terms, are large enough to move the markets by more than $10 \%$ during a trading period. The absence of large capitalization companies in world terms keeps foreign investment funds from investing in the Baltics because they typically place limits on the total percentage of outstanding shares in one company that they can own.

\subsubsection{Estonia}

The Estonian market is small (the biggest stock on the Tallinn Stock Exchange (TSE) - Hansabank - has a market capitalization of just US\$320 million), liquidity-driven, and extremely emotional. On February 25, 2002 Tallinn Stock Exchange (TSE) and its member firms adopted the trading system of HEX, thus creating a common trading environment for securities listed on the Tallinn and Helsinki exchanges. The official trading currency is euro. The investors can still pay for transactions in Estonian kroons with no extra charge. Securities which were listed on the TSE before its acquisition are still listed on TSE, not on the Helsinki Stock Exchange, and are governed by the Rules and Regulations of the TSE [2].

The main advantage of the Estonian equity market relative to those of other Baltic countries is its tolerable liquidity and new strategic investor. "Integrating the Estonian securities market into international structures is a major strategic priority for the Tallinn Stock Exchange. We believe that this would mean much easier access for investors and better visibility for local 
companies, therefore enhancing the liquidity and attractiveness of the Estonian capital market," stated Gert Tiivas, CEO of TSE. And he was quite right: the new trading system and transparency of the TSE have successfully attracted foreign investors: approximately $45 \%$ of the total quoted shares are owned by foreigners, with Finland and the United Kingdom heading the list. Local investors have also been very active participants, adding to the liquidity of the market. The main drawback of Estonian stock market is its size; the market capitalization of its 15 quoted companies totals just 2.271 billion EUR, which is comparably small in world terms (2003 last quarter). Moreover, the market is strongly dominated by the banking sector with Hansabank, being the most influential blue chip. Since 1998 more industrial companies, which were far less risky and less expensive joined the list. Because of this second place in terms of capitalization is taken by Eesti Telekom, about $33 \%$. So diversification in companies is quite low at the present. Besides, the market crash in October 1997 (during which the market index fell by $54 \%$ in 30 days) showed how vulnerable banks can be during worldwide crises [3]. The Estonian equity market has had a promising start, but it will probably not be the region's leader due to its small capacity yet.

TSE authorities formerly also were blamed because of the lack of the regulations and mechanisms needed to control securities market. In general the regulation of the Estonian stock market were quite loose compared to Latvia and Lithuania, and the Finance Ministry's Securities Inspection unit had little power; its main function were and still is to issue licenses to brokers. So as Estonia moved further down the path of European integration, its market regulations needed to be tightened. With new owner things began to change. I was commented by Sandra Meigas, Marketing and Public Relations Specialist from Tallinn Stock Exchange / Estonian CSD that new legal act were applied in order to enhance trade: "For example Listing Rules of TSE's Rules and Regulations were amended in order to enhance trading activity of the debt securities market. Proceeding from the new provision nominal value of debt securities submitted for listing has to be either in Estonian kroons or euros. Also time limits of interim report disclosure were harmonised with instructions of the Estonian Accounting Standards Board, requirements of periodic reporting for issuers of debt securities and investment funds were amended, requirements for Main List market capitalisation were decreased from 300 million EEK to 62 million EEK (4 million euros)." The comment shows that Estonian securities market is integrating in European market successfully and actively. The use of such strategy which is the first of its kind among Baltic States gave an advantage to TSE.

Since 1998 the Estonian stock market increased because of the privatization of a few large infrastructure companies, such as Estonian Telecom and Estonian Shipping Company, and by the likelihood of some large mergers. Beginning in 1998 the market capitalization was 519 millions US\$. Because of the facts mentioned above, like privatization, acquisition by strategic investor it has raised to its current position: 2.271 billion EUR. It shows that the strategy implemented by the authorities of TSE was right and it overcame other two exchanges located in Baltic States.

\subsubsection{Latvia}

After restoration of independence, the Riga Stock Exchange was founded in December, 1993. The first step taken was to conduct an extensive search for the most appropriate stock exchange model. The Exchange's trading and quoting model was designed in compliance with G-30 recommendations and in close cooperation with the Paris Bourse and the Central Depository of France (SICOVAM). It is similar to the system successfully implemented in Poland, the Czech Republic and Lithuania. Besides operating as a typical exchange, the Riga Stock Exchange has also been involved in the Latvian public privatisation programme. Privatisation of state-owned companies for privatisation vouchers provided a new direction for the development of capital market in Latvia. The Riga Stock Exchange was selected to be the agent of the Latvian Privatisation Agency, and so became actively involved in the public offering programme. Nearly all companies currently listed on the Riga Stock Exchange are the result of public privatization.

The Riga Stock Exchange (RSE), launched in 1995, has advanced from an ineffective single-price singlefixing system into a continuous trading system with automatic trade matching which existed till 2002. However, the RSE represents only a small component of the Latvian economy: there are eight companies included on the official list and twenty-three on the secondary list, and their total combined market capitalization is only US\$664,8 million at the end of the year 2002. With the exception of the shares of Unibanka, Latvia's second largest bank, liquidity has always been a luxury on the RSE. 
In 1998 market participants expected Latvia to be the emerging Baltic stock market because of the privatization of large infrastructure companies like Latvian Gas and Latvian Shipping Company. It was expected that market capitalization would raise beyond 2 billion US\$. But instead Latvia remains the smallest stock market: at the year 2001 the capitalization was 697 millions US\$ [4].

\subsubsection{Lithuania}

While Estonia and Latvia are often praised for the rapid developments and integration of their equity markets, Lithuania is still regarded as a sleeping giant.

In Lithuania the organized trading of securities (shares, rights, Treasury bills, corporate and government bonds) on the secondary market takes place at the National Stock Exchange of Lithuania. The enactment of the first Company Law in 1990, which introduced public stock companies as a type of corporate entities, entailed an urgent need for the creation of the securities market that would be efficient, well regulated and supervised. Development of the Lithuanian securities market began in 1992 when the National Stock Exchange of Lithuania and the Securities Commission of the Republic of Lithuania were established. Since September 14, 1993 private securities in Lithuania are traded on the National Stock Exchange of Lithuania (NSEL) which is based in capital Vilnius. This was the first stock exchange in the Baltic countries to be opened in the post-Soviet period. NSEL was opened with the assistance of the French Government and the Paris Bourse. The Paris
Bourse has introduced the same French systems at the Warsaw, Prague, and Kiev stock exchanges.

Although it is the oldest and the largest, National Stock Exchange of Lithuania (NSEL) has been an unsuccessful since its first trade in 1993. At the beginning an ineffective and incomprehensible trading system with a single price fixing per day and a price fluctuation limit of ten percent have resulted in low liquidity and have scared away most foreign and many local investors (Figs. 2, 3). Also government's position not to sell privatizing companies trough stock exchange but rather through direct negotiations have slowed the development and trust in the exchange.

Fortunately, NSEL has recognized the problems and changes are on their way: from autumn 1998 NSEL employed a new trading system which, unlike the old Estonian one which now is changed by the HEX trading system, is expected to feature automatic trade matching. Also there are maintained both trading models: single fixing and continuous trading. To say the truth this did not solve all of the liquidity problems, but it certainly made trading easier, enabling the investor to know the exact price and amount he is getting.

In the long run, Lithuania has the potential to become the leading Baltic stock market. It is certainly the largest: there are about 800 companies totally listed on the NSEL and its market capitalization is about 3.7 billion EUR.

And Lithuania's macroeconomic environment is quite favorable: the country is the largest in the Baltics, its GDP is based mainly on industrial sector, and its

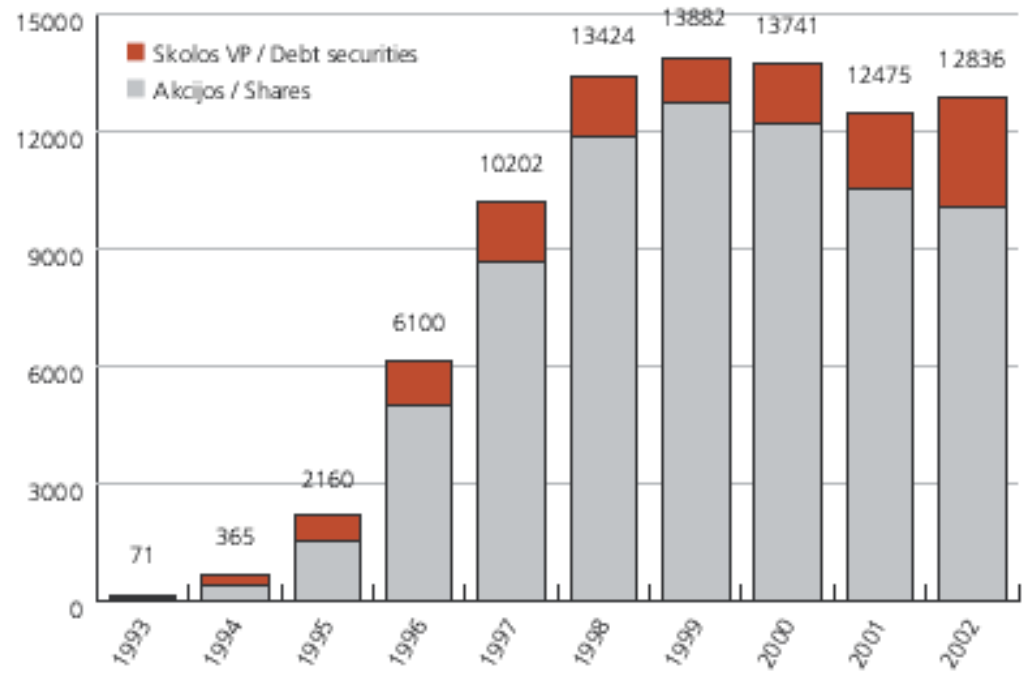

Capitalisation (LTL mill)

Fig. 2. Total market capitalization on NSEL [5] 


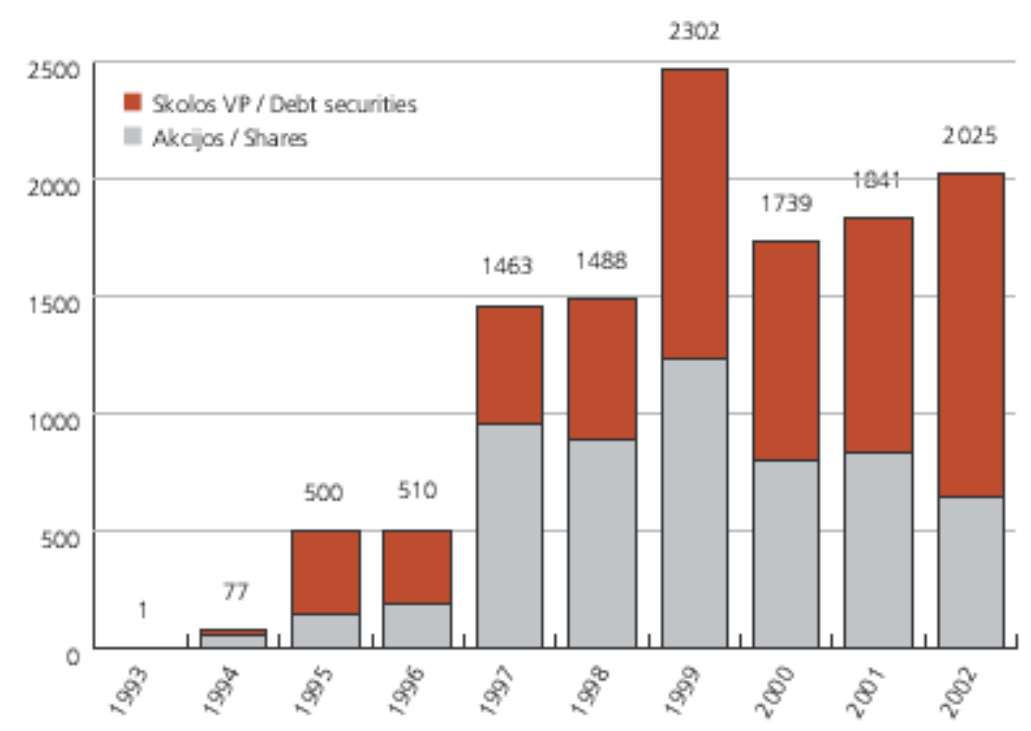

Total turnover (LTL mill)

Fig. 3. Total turnover on NSEL [5]

growth is slower so the threat of economy overheating is smaller.

Another strength of the Lithuanian stock market is its strict rules regulating transactions. In fact, Lithuania's stock market laws and broker requirements are the closest to EU laws. Because of it since 1998 the number of companies on the main list diminished dramatically: from 607 in the year 1997 to 60 in the year 1998. Lots of companies could not fulfill the new listing requirements and in that way they have been transferred to position of not-listed. But evidently, more money and time are needed for this relatively large market to fulfill its potential.

\subsubsection{Comparison of Tallinn, Riga and Vilnius stock exchanges}

Development of some key characteristics of the Baltic stock exchanges over the last several years is presented in Table 3. In terms of total market capitalization the NSEL has been a clear leader in the Baltics throughout all the period considered. It has been twice as capitalized as the TSE and several times as capitalized as the RSE. The latter can be partially explained by larger size of the Lithuanian economy and lower capital requirements needed to enlist a company on the exchange 29. When the size of the economy is taken into account the capitalization of the

Table 3. Basic figures of Baltic stock exchanges

\begin{tabular}{|c|c|c|c|c|c|c|c|}
\hline & 1995 & 1996 & 1997 & 1998 & 1999 & 2000 & 2001 \\
\hline \multicolumn{8}{|c|}{ Total market capitalization, USD million, end of the period } \\
\hline TSE & n.a. & 720.2 & 1126.6 & 533.3 & 1837.0 & 1764.6 & 1502.3 \\
\hline RSE & 9.7 & 151.4 & 336.9 & 397.3 & 393.1 & 567.7 & 687.4 \\
\hline NSEL & 540.0 & 1525.0 & 2550.5 & 3356.0 & 3470.5 & 3435.3 & 3118.8 \\
\hline \multicolumn{8}{|c|}{ Total market capitalization to GDP ratio, \%, end of the period } \\
\hline TSE & n.a. & 17.1 & 25.0 & 9.7 & 37.2 & 36.0 & 27.6 \\
\hline RSE & 0.2 & 3.0 & 6.1 & 6.3 & 5.9 & 8.0 & 9.3 \\
\hline NSEL & 9.0 & 19.3 & 26.6 & 31.2 & 32.5 & 30.4 & 26.0 \\
\hline \multicolumn{8}{|c|}{ Total turnover, USD million } \\
\hline TSE & n.a $_{i}$ & $190.7^{\mathrm{a}}$ & 1575.3 & 948.6 & 304.8 & 326.3 & 235.1 \\
\hline RSE & $0.2^{\mathrm{b}}$ & 12.7 & 84.3 & 85.5 & 50.1 & $915.3^{\mathrm{c}}$ & $844.9^{\mathrm{c}}$ \\
\hline NSEL & 125.0 & 127.4 & 365.8 & 372.0 & 575.5 & 439.8 & 460.3 \\
\hline \multicolumn{8}{|c|}{ Share market turnover in total turnover, $\%$} \\
\hline TSE & 0.0 & 99.4 & 99.9 & 99.8 & 97.8 & 92.1 & 94.2 \\
\hline RSE & 12.5 & 93.6 & 100.0 & 100.0 & 85.9 & 30.3 & 19.4 \\
\hline NSEL & 29.7 & 37.1 & 65.5 & 59.9 & 53.7 & 46.0 & 45.6 \\
\hline
\end{tabular}

Note: ${ }^{a}$ - 1996 June-December; ${ }^{b}$ - 1995 March-December; ${ }^{c}$ - trade turnover outside the market included. Source: Baltics' stock exchanges. 
TSE and the NSEL become similar. The RSE, in terms of capitalization and its share in GDP, remains far behind the corresponding indicators both of the NSEL and TSE.

Looking back at the economic factors the difference between the Baltic States was and still is evident (Fig. 4). Economic growth in Estonia remained strong in 2002, despite the weakening global economy. The Bank of Estonia estimated the gross national product to increase by 5.3 per cent. The acceptance of Estonia to join the EU and NATO in 2004 brought more confidence to continuing growth, as did the fact that Moody's upgraded Estonia's credit rating to class A1, one of the best in Central and Eastern Europe. Lithuania and Latvia also gained international recognition and were accepted as members of the European Union and NATO starting in 2004. The international alliances are expected to have a continuing positive effect on all three economies.

2002 was also a year of success for the Latvian national economy. The Latvian central bank estimated the gross national product to increase by 5.7 per cent. Economic stability was reflected by the upgrade in Moody's credit rating from Baa2 to A2.

Lithuania in that context did not look too good: the country was graded the lowest, at Baal in Moody's credit rating. In fact this rating is the lowest among all 12 European Union candidate countries. While at the same time Estonia was ranked third and Latvia sixth in Moody's credit rating. Rating agency grades influence the market ratings of debt securities issued by a given country. The higher the rating, the higher the price of the securities. After the new Moody's rating was announced, the quotations of Lithuanian bonds were the lowest among all candidate countries. That means that the costs of raising funds in the next bond issues made by the Ministry of Finance will not be higher then in our countries and Lithuanian is not going to capitalize on this like other accession countries. Besides, Lithuanian businesses will not find it easier to raise funds in the international capital market.

The positive development was reflected in the Estonian securities market, which was one of the most successful in the world. The TALSE Index reached its four-year high in December 2002 and closed at 212 points, 43 per cent higher than at the beginning of the year. The total value of share trading in the stock exchange increased slightly from the previous year to 266 million euro. The increased number of institutional long-term investors and decreased number of private investors reduced the number of share trades in the stock exchange. The turnover velocity decreased to 12 per cent from 16 per cent in 2001. And only one slight drawback that was indicated was the diminishment of a number of listed companies.

Corporate arrangements reduced the number of listed companies from 17 to 14: the global slowdown in the listing market was also visible in Tallinn; no new companies were listed during the year.

During the same period the share trading volume in Riga Stock Exchange in 2002 was 181 million euro. The RICI Index increased by 27 per cent during the year, closing at 207 points. The Latvian market saw the largest listing of its history when 51 per cent of the shares in Latvian Shipping Company (Lasco) were

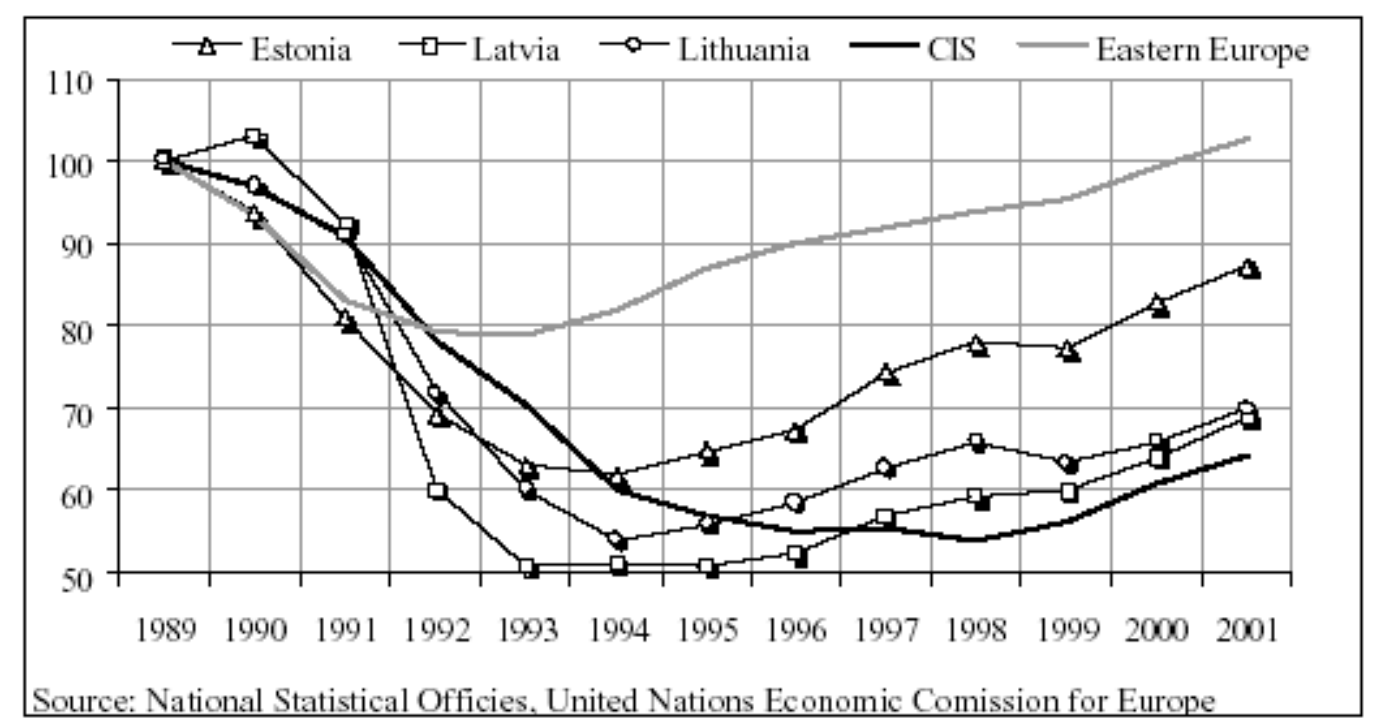

Fig. 4. Real GDP dynamics in the Baltics, Commonwealth of Independent States, and Eastern European economies, $1989=100$ 
auctioned in the Riga Stock Exchange in July. All the offered shares were sold and the value of the auction amounted to 60.7 million euro. This showed government's concern to revivify the growth of stock market by privatizing large companies through the Stock Exchange.

The National Exchange of Lithuania during 2002 has acquired a completely new status: from a non-forprofit organization the institution was transformed into a profit-seeking company. Although the decline tendencies prevailing in the global capital markets did to an extent affect the Lithuanian capital market, the exchange has succeeded in preventing the deterioration of the market. Quite conversely, during the year the trading turnover on the Exchange has augmented by 10 per cent and exceeded EUR 580 million. The rise in share price has pushed upwards share indices too: LITIN-10 went up by 17.7 percent and LITIN-G by 6.6 per cent. During 2002, the Exchange saw 37.5 thousand transactions concluded, over 508 million securities bought and sold, the total turnover exceeding that of 2001 by almost $10 \%$. Trading in debt securities accounted for $68 \%$, or EUR 397 million, which augmented by $37 \%$ per year. The Exchange capitalization augmented by $2.89 \%$, to EUR 3,721 million, and capitalization of listed securities increased by $12.08 \%$, to EUR 2,197 million.

Estonia nowadays is regarded as the most advanced in terms capital markets in the Baltic States. And there is a serious reason for this: Retail investors' increased tendency to invest via professional fund managers (annual fund inflow and number of fund unit holders doubled compared to previous year) and emergence of local pension funds indicate the further institutionalization of the market. Mostly this position was gained because of successful merger with Finnish HEX Group. The transition to the HEX trading system brought four new members to HEX Tallinn. There were 13 trading members at the end of the year 2002 . The first remote account operator started to operate in the Estonian Central Securities Depository during the year. The operations of HEX Back Office and Custody Services Ltd, part of the HEX Group, make it easier for foreigners to invest in Estonian securities. The HEX trading environment brought a further increase in foreign ownership of Estonian securities. The share of foreign investors increased to 81 per cent from 78 per cent a year earlier.

Latvia is still being considered as the "second" stock exchange in terms of development. At the end of 2002 the shares of 62 companies were quoted in the Riga Stock Exchange, with a total market value of 686 million euro. Riga Stock Exchange continued to be the leading marketplace for debt instruments in the Baltic countries, with a total trading volume of 328 million euro. The increased stability of the national economy has made long maturity times of bonds more common not only in the public sector but in private bonds as well. Also the state pension system is just expected to bring new capital to the market. In Latvia, starting in the beginning of 2003, the voluntary pension fund market was opened for private fund companies as well.

And again Lithuania is quite far behind its smaller neighbors. The reform of pension system is at its end, but so far there are no pension funds. And in my opinion they play very important role today. If we compared the trading volume, capitalization of recent years, we would see that since the beginning of 20012002 in Estonian Stock Exchange these numbers increased very sharply. In Latvia stock market is also beginning to rise. Since both these exchanges now belong to HEX group, some might think that this entire boost is because of new orientation of exchanges. But in my opinion in this case namely pension funds are the ones to blame. Just in Estonia as of end of March 2003, some 215,390 people joined the funded pension system since its introduction last year. The amount of funds in the second pillar funds was about 19 million EUR. Analysts expect this amount to reach 51 millions EUR by the end of this year. That shows that funds were supplied with capital and this capital had to be invested. Part of this capital is about to flow into local listed companies. From this point the merger with HEX group begins to play an important role. Since Estonian securities market is so tiny, there would be no opportunities for diversification and for serious investments at all. But now for Estonian investors comparably big Finnish market is open. So the part of investments, as I have mentioned earlier, went and will go to local, and another part to foreign markets. Very soon the same technique will be adopted in Latvia. Latvia launched the second pillar late last year and has partly adopted the Estonian funded pension system model. This system showed to be effective in two countries and can be successfully copied to a number of other countries. Lithuanian should not be very far away in this case, but still I think we have to wait a bit longer to see it work in our country.

It is evident that all three exchanges are too small to be interesting to investors and to stay alive. Understanding the importance of situation, all thee exchanges signed the Memorandum of Understanding on 23 April 1999. The aim was to harmonize the three 
markets into a single investment area, which would be a liquid, attractive and easily understandable market for the international investor community. This was the first step towards creation of single Baltic market. The idea behind it is evident: investors usually do not know each country in this region, and markets, if taken separately, are far too small to be interesting, so creating new market, Baltic marked, was in favor for all three states. The principles of cooperation also were designed seriously: exchanges remain independent entities, electronic cross-linking of trading systems, synergy from joined activities, facilitation of cross membership, harmonization of rules and cooperation on access into an international exchange alliance. On January 3, 2000 exchanges launched a list of Baltic blue-chip securities. The list still exists and it consists of up to 15 largest firms listed on the Official Lists of the three Exchanges, whereas no more than seven can be from one country. The composition of the list is reviewed quarterly by the Exchanges. Today Lithuanian companies have six companies in the list. The aim of the list is to help investors to better focus on the Baltic region and its blue-chip companies. The peak of cooperation was reached on May 2, 2000, when all exchanges signed a Letter of Intent aiming at partnership in the NOREX exchange alliance. Baltic exchanges were given an option to become partners in the alliance at a later point in time. But this partnership was never to happen. In February 2001 Tallinn called it quits. "It has proven difficult to reconcile needs of the larger existing Norex exchanges with the smaller emerging Baltic markets," the alliance said in a statement with the Riga and Vilnius exchanges. There also were some rumors that the "price" for joining was too high for small Baltic exchanges. As Tallinn and HEX, as the Helsinki Exchanges are called, strived to launch the joint trading on the year 2002, the Latvia and Lithuania exchanges remained unaffiliated, but said that they are considering several unspecified offers for cooperation. So from 2002 the TSE has become a subsidiary of the HEX and adopted the Finnish trading system. At the same time, the NSEL moved quickly to sign a cooperation agreement with the Warsaw stock exchange. Furthermore, in July 2002 the HEX acquired 93 percent of the RSE stocks.

Talk held with NOREX Alliance turned out to merger, first of all, between Tallinn and Helsinki exchanges and latter HEX also acquired Riga Stock Exchange. And what concerns Lithuania, since that moment the country is still considering possible merger scenarios up to now.

\subsection{Importance of Privatization}

Today Lithuanian companies still have great difficulty raising funds through securities issues, while most ventures find it altogether impossible. On the other hand, investors are very limited in their choices: seven stocks are listed on the blue-chip Official List and 41 issues on the Current List of the National Stock Exchange. The main problems of the capital market stem from the absence of institutional investors, petty regulatory constraints on market participants (investors, issuers and traders) and a state policy impeding market development.

The material, presented below, is for the purpose of clearing out the reasons which determine passive circulation of stock and propose offerings which would enable Lithuanian capital market contribute to the growth of the economy.

Legal and institutional preconditions are made for stock market in Lithuania. As it is mentioned before essentials of Lithuanian stock market were being created in 1992. It was very important to establish the right legal and institutional base from the beginning of economical reforms. And today the advance is clearly visible. Without the Stock Exchange today all institutions required for effective working of securities market are present: Securities Commission, Central Securities Depository of Lithuania, financial intermediaries.

Despite the fact that today legal base regulating the nexus in stock market and it seems that possibilities for development are permitted, the market does not perform the role it should. Lithuanian stock market does not use its potential insomuch that economy would grow faster, while offering for people comfortable capital trading instruments. In programs of Lithuanian governments traditionally there were obligations for stimulation of development of Lithuanian securities market. Only during years 2000 - 2002, few of motivation means were introduced: restrains for the number of buyers and selling securities were resigned, the tax for capital increase was cancelled, the procedure for soak of securities was simplified, restrains for prices of securities in direct negotiations were withdraw, at the year 2001 new Civil codex came into action. Unfortunately, it did not give desirable impulse for securities market.

The passivity of Lithuanian stock market, even with the presence of favorable environment, motivates the search for others, not only legal and institutional means, which would contribute to the positive and desired development. 
There is more than one reason why securities market does not perform its role. These reasons could be grouped into a few big clusters. And names of groups are following: financial, administrational and cultural.

Financial shoal are deeply connected with state's borrowing policy. The current fiscal policy heightens the risk of capital market investments, makes the country less investment-attractive, and increases borrowing costs. Because the treasuries market is so appealing, due to its profitability and safety, it absorbs investor capital, essentially diverting investment flows away from the private sector securities market.

Administrative or procedure obstacles are connected with plenty and complicated legal acts. Instead of safeguarding the safety of securities market, regulatory means cause negative additional result - torpidity of the market. Excess regulations for safeguarding small investors determine that companies, their large shareowners elude to organize business with other owners commonly. Again there is drive to hide profit, not to pay dividends or to get them in indirectly. All this leaves small investors unsecured and without any motivations to use the services of securities market. The decision to privatize government's companies not trough the stock exchange also testifies that the government itself, for hardly explainable motives, are using market mechanism reluctantly and thus deepening the stagnation.

The situation in stock market also depends on traditions of managing enterprises, are they vital in Lithuania, or weak. The center of financial attraction in Lithuania is evidently in commercial banks, when even potential buyers of securities (small and medium investors) usually limit their actions by depositing their capital into banks and potential capital buyers are looking for financial resources not on capital market but in commercial banks. This financial instrument is more common, and it also helps to avoid so unloved bureaucracy.

Today there are several financial institutions that could be regarded as potential strategic investors. These are: HEX Group, Warsaw Stock Exchange and, according to BNS, Bank for Reconstruction and Development.

In opinion of experts, Lithuania should go along with to other Baltic States. In such way one big capital market of Baltics will be formed and for foreign investors that would be an easier way to invest in Lithuanian securities. Also HEX group today is more experienced in terms of integrating small exchanges into its network, because successful implementation of all technical features already is done in Tallinn and soon will be over in Riga - exchanges so similar to Lithuanian one. HEX name is also of more importance in European capital markets than Warsaw Stock Exchange's and merger with it would put NSEL into new level.

\section{Conclusions}

In order to benefit from those securities markets trends fully, it is important that the Lithuanian authorities today devise a strategy for the national marketplace that allows for deep, smooth and quick integration with the European structures. In our opinion, the best way to accomplish this is by integrating Lithuanian marketplace institutions with one of the alliances in Europe and by inviting this organization as a strategic partner and investor to NSEL and CSDL.

Thus, it can be said that the privatization of NSEL and CSDL should not be viewed as a goal in itself, but rather as an enabling step for consolidation and integration of the Lithuanian market with European structures. Further, the suitable method for finding the partner with best fit is tender, where all interested candidates will be able to present their visions and offers, after which the Lithuanian authorities and stakeholders can choose the best option.

1. The development of the securities markets is an important contributor to economic growth. Developed securities markets offer financial intermediation at lower than the banking sector cost, diminish informational asymmetry in the economy, and allow allocating risks efficiently. In terms of fiscal policy it allows the government to run a balanced budget without altering the taxes and/or expenditures each period.

2. Legal and institutional prerequisites for the development of Lithuanian securities market are established, but the market still does not use fully its potential and does not contribute to the growth of economy.

3. The future of Lithuanian securities market and its vitality can be associated only with processes of globalization and integration into world's capital movement.

4. Rational and economically based decision according the future of National Stock Exchange of Lithuania can be taken only by private owner, who is interested in effective work of the exchange.

5. It seems that the TSE and RSE have already made their decision while the direction of future 
international integration of the NSEL is rather uncertain. One conclusion, however, seems to be clear - after the privatization process is over the Baltic stock exchanges will not survive unless further steps towards greater integration into larger and more liquid European stock exchanges are undertaken.

6. Over the last decade it became clear that the Baltics have most in common with Europe's Nordic countries.

7. Further progress in pension reforms is also desirable in terms of enriching the financial markets in the Baltic States.

\section{References}

1. www.fese.com

2. Estonian Securities Market: Factbook of HEX Tallinn; January to March 2003; Tallinn 2003

3. Estonia's progress report - June 2000; Tallinn

4. The year of transformation; RSE, Latvia 20015

5. Annual report 2002; National Stock Exchange of Lithuanian, Vilnius 2003 